\section{Poly(I:C) のヒラメに対する毒性}

\author{
松井崇憲・点 明柱・西澤豊彦*
}

(2012年 4 月25日受付)

\section{Toxicity of Poly(I:C) against Japanese Flounder Paralichthys olivaceus}

\author{
Takanori Matsui, Myung-Joo Oh \\ and Toyohiko Nishizawa* \\ Department of Aqualife Medicine, Chonnam National \\ University, Yeosu 550-749, Republic of Korea
}

(Received April 25, 2012)

\begin{abstract}
We evaluated the effect of rearing temperature $\left(13\right.$ and $\left.17^{\circ} \mathrm{C}\right)$ on the toxicity of Poly $(\mathrm{I}: \mathrm{C})$ against Japanese flounder Paralichthys olivaceus (mean BW $8.2 \mathrm{~g}$ ). In the fish reared at $17^{\circ} \mathrm{C}$, we observed signs of toxicity such as redness or ulceration of the skin around the inoculation site or death in $41.7 \%, 16.7 \%$, $16.7 \%$ and $0 \%$ of the fish injected with $800,400,200$ and $100 \mu \mathrm{g}$ Poly(I:C)/fish, respectively. In the fish reared at $13^{\circ} \mathrm{C}$, we observed signs of toxicity in $83.3 \%, 75.0 \%$, $25.0 \%$ and $33.3 \%$ of the fish that were injected with 800 , 400, 200 and $100 \mu \mathrm{g}$ Poly(I:C)/fish, respectively. Our results suggest that the toxicity of Poly $(\mathrm{I}: \mathrm{C})$ is higher in Japanese flounder reared at $13^{\circ} \mathrm{C}$ than in those reared at $17^{\circ} \mathrm{C}$
\end{abstract}

Key words: VHSV, live vaccine, toxicity, Poly(I:C), Paralichthys olivaceus, Japanese flounder

ウイルス性出血性敗血症（viral hemorrhagic septicemia: VHS）は，本来ニジマスの病気として欧州では古くから 知られていたが，1999年に日本沿岸の天然ヒラメ (Paralichthys olivaceus) から VHSV が分離されて以 来 ${ }^{1,2)}$ ，日本打よび韓国に扔けるヒラメの養殖産業に甚大 な被害をもたらしている ${ }^{3,4)}$ VHSV は, ラブドウイルス 科のノビラブドウイルス属に属するウイルスで，日本お よび韓国の VHSV 株は何れもゲノグループIVaに分類さ れ，欧米株とは若干異なると考えられている ${ }^{5-7)}$ 。これま でにVHS 対策の一つとして，フォルマリン不活化ワクチ ン, サブユニットワクチンおよびDNA ワクチン等, 様々 なワクチンが研究・開発されてきた ${ }^{8-11)}$ 。近年，インター

全南大学校 水産生命医学科

* Corresponding author

E-mail: jjnishi@chonnam.ac.kr
フェロン誘導物質である合成 2 本鎖 RNA［polyinosinicpolycytidylic acid, Poly (I:C) ] を投与することでヒラメを 抗ウイルス状態とし，この間にVHSVを接種することで, 魚を殺すことなしにVHSV に対する特異免疫を誘導する， いわゆる Poly (I:C) -免疫法の有効性が報告された ${ }^{12)}$ 。本 免疫法は, ニジマス (Oncorhynchus mykiss) の伝染性 造血器壊死症 (infectious hematopoietic necrosis, IHN) およびマハ夕 (Epinephelus septemfasciatus) のウイル 又性神経壊死症 (viral nervous necrosis, VNN) でも有効 であることが報告されている ${ }^{13-15)}$ 。Poly (I:C) をヒトに投 与すると, 腎不全や過敏症などの副作用が認められるが 16)，魚類での副作用についてはほとんど報告されていな かった。ヒラメのVHS に拈けるPoly (I:C) -免疫法の適温 は $17^{\circ} \mathrm{C}$ であるが， $13^{\circ} \mathrm{C}$ では Poly (I:C) 投与による毒性

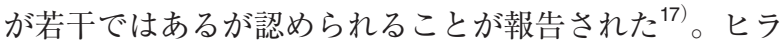
メの VHS は, 春先の低水温期に発生する病気であること から，将来的に低水温期にVHSV を用いたPoly $(I: C)$-免 疫法を実施する可能性が十分に考えられる。そこで本研 究では, $13^{\circ} \mathrm{C}$ および $17^{\circ} \mathrm{C}$ で飼育したヒラメに 100 800 $\mu \mathrm{g}$ のPoly (I:C) を投与し, その毒性について検討した。

供試魚として, Chonnam National University 水産研究 所で飼育されていた平均体重 $8.2 \mathrm{~g}$ のヒラメ計120尾を用 いた。計 10 個の $4 \mathrm{~L}$ 水槽を準備し, 5 個の水槽の飼育水 温を $13^{\circ} \mathrm{C}$ に, 残る 5 個の飼育水温を $17^{\circ} \mathrm{C}$ に設定後, 各 水槽にヒラメを12尾ずつ収容し，12日間馴致させた。馴 致後, Poly (I:C) (Sigma) を滅菌 DEPC 処理水に溶解 し， 800，400，200 および $100 \mu \mathrm{g} / 100 \mu \mathrm{L} /$ fish となるよ う筋肉内に接種した。なお，実験対照区のヒラメには, DEPC 処理水を $100 \mu \mathrm{L} / \mathrm{fish}$ となるよう筋肉内に接種し た。Poly (I:C) 接種後, 10日間各水温で飼育し, 死亡率 の推移ならびにヒラメの外観上の変化を観察した。

ヒラメを $17^{\circ} \mathrm{C}$ で飼育し, Poly (I:C) を $800 \mu \mathrm{g} / \mathrm{fish}$ 接 種した区では，接種後 2 日目に 1 尾死亡したのみであっ た（累積死亡率8.3\%, Fig. 1-A)。また, Poly(I:C) を 800,400 および $200 \mu \mathrm{g} / \mathrm{fish}$ 接種した区では，各々4尾 (33.3\%)，２尾（16.7\%）拈よび 2 尾（16.7\%）に，接 種部位付近の皮膚が赤く変色し, やがて潰瘍が形成され, 最終的には筋肉が露出するという外観上の変化が観察さ れた（Figs. 1-B，2）。この外観上の変化は，接種後 2 5 日目から観察され，皮膚の損傷が軽度の場合には試験 期間内に回復するものもあったが，多くの個体では回復 せず，筋肉が露出したままであった。なお， $100 \mu \mathrm{g} / \mathrm{fish}$ 接種した区では死亡ならびに外観上の変化は認められな かった。

一方， $13^{\circ} \mathrm{C}$ で飼育したヒラメにPoly (I:C) を 800 およ び $400 \mu \mathrm{g} / \mathrm{fish}$ 接種した区では，接種翌日から死亡が始ま り，試験終了時の死亡率は66.7\%および41.7\%であった (Fig. 1-C)。また, Poly(I:C) を $200 \mu \mathrm{g} /$ fish 接種した区 

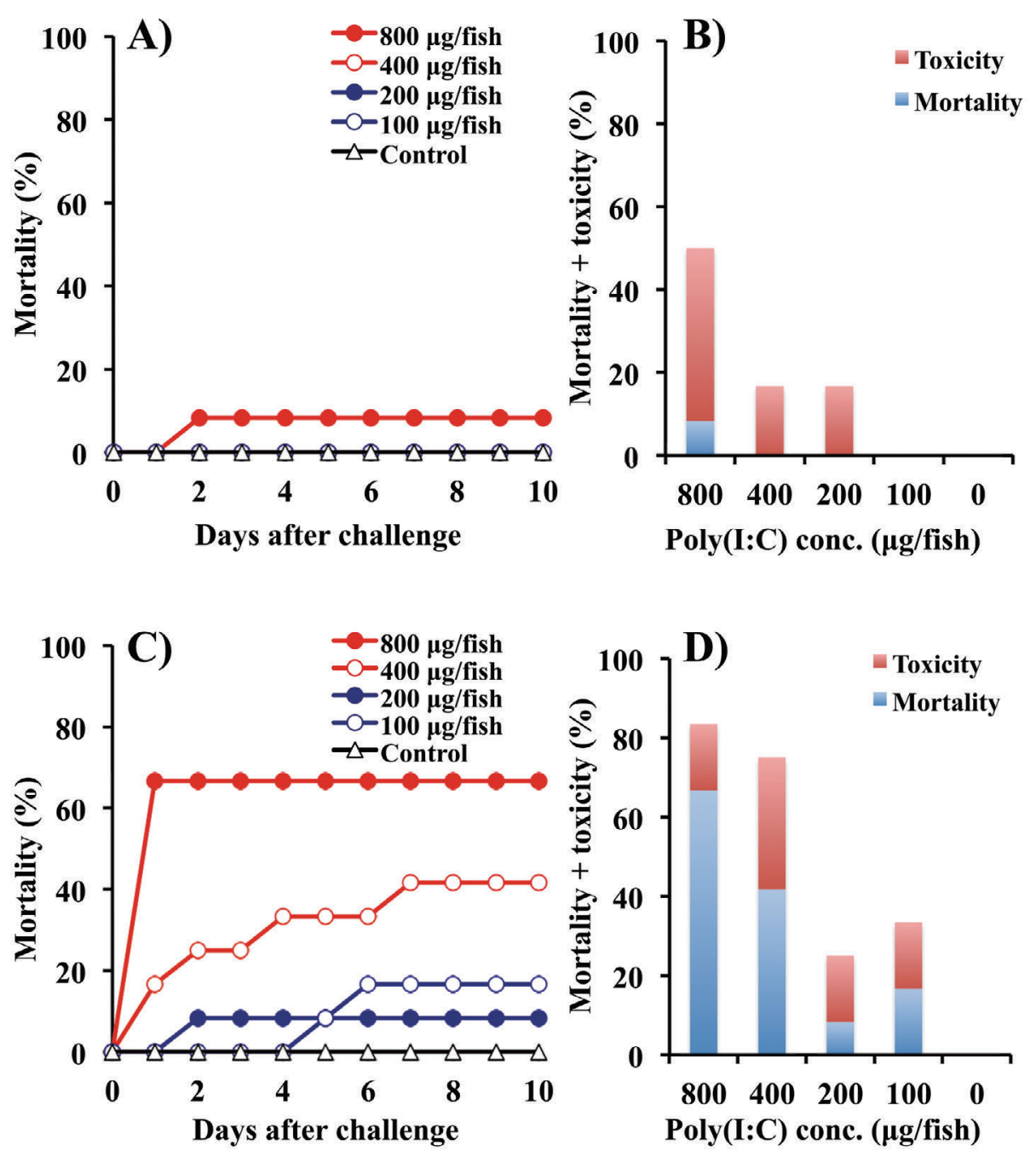

Fig. 1. Toxicity of Poly (I:C) against Japanese flounder reared at $17^{\circ} \mathrm{C}$ and $13^{\circ} \mathrm{C}$. A) and C) mortality curves of fish, B) and D) total rates of lethal, redness of skin or ulceration in the skin around the inoculation site, A) and B) fish reared at $17^{\circ} \mathrm{C}, \mathrm{C}$ ) and $\mathrm{D}$ ) fish at $13^{\circ} \mathrm{C}$.

では，接種後 2 日目に 1 尾が，また $100 \mu \mathrm{g} / \mathrm{fish}$ 接種した 区では接種後 2 日目㧍よび 5 日目に 1 尾ずつ計 2 尾が死 亡し，各区の累積死亡率は各々 $8.3 \%$ および16.7\%であっ た（Fig. 1-C)。また, 800, 200 および $100 \mu \mathrm{g} /$ fish 接種 区の16.7\%で，また $400 \mu \mathrm{g} / \mathrm{fish}$ 接種区の33.3\%で，皮膚 の赤変㧍よび潰瘍形成などの毒性が認められた（Fig. 1D)。

なお，DEPC 処理水を接種した実験対照区においては, 飼育水温が $17^{\circ} \mathrm{C}$ および $13^{\circ} \mathrm{C}$ の何れの区においても死亡 ならびに外観上の変化は認められなかった（Fig. 1)。

以上の結果をまとめると, $17^{\circ} \mathrm{C}$ 飼育区では, 800 $\mu \mathrm{g} / \mathrm{fish}$ 接種区の 1 尾以外で致死毒性は認められなかった が， $\geq 200 \mu \mathrm{g} / \mathrm{fish}$ 接種区で16.7\% 33.3\%の魚に皮膚の 変色あるいは潰瘍形成などの毒性が認められた。これ に対し $13^{\circ} \mathrm{C}$ 飼育区では，800 $\mu \mathrm{g} / \mathrm{fish}$ 区で $83.3 \% ， 100$ $\mu \mathrm{g} / \mathrm{fish}$ 区でも33.3\%の魚で致死毒性, 皮膚の変色あ
るいは潰瘍形成が認められた。即ち， $13^{\circ} \mathrm{C}$ 飼育における Poly (I:C) のヒラメに対する毒性は $17^{\circ} \mathrm{C}$ 飼育に比べ大幅 に高いことが示された。合成 RNA である Poly (I:C) は, 魚体内の RNase により速やかに分解されるため, 高温飼 育での毒性が相対的に低いことは容易に推察されるが, わずか $4^{\circ} \mathrm{C}$ の違いでPoly (I:C) の毒性にこれ程の差異 が認められたことは興味深い結果である。Nishizawa et al. ${ }^{17)}$ は, $13^{\circ} \mathrm{C}$ で飼育したヒラメに $200 \mu \mathrm{g} / \mathrm{fish} の$ Poly (I:C) を接種した場合, 一部の魚で致死毒性が認めら れることを指摘した。本実験結果は，これを改めて裏付 ける結果である。ヒラメでは, $17^{\circ} \mathrm{C}$ で Poly (I:C)-免疫法 を実施することで, 最も高い予防効果が誘導されること が報告されている ${ }^{17)}$ 。また，ヒラメでは，Poly(I:C) を $12.5 \mu \mathrm{g} / \mathrm{fish}$ 接種することで90\%の魚が，また $25 \mu \mathrm{g} / \mathrm{fish}$ 接種することで $100 \%$ の魚が抗ウイルス状態になること から ${ }^{12)}$, Poly (I:C) による毒性を考虑する必要性はない 

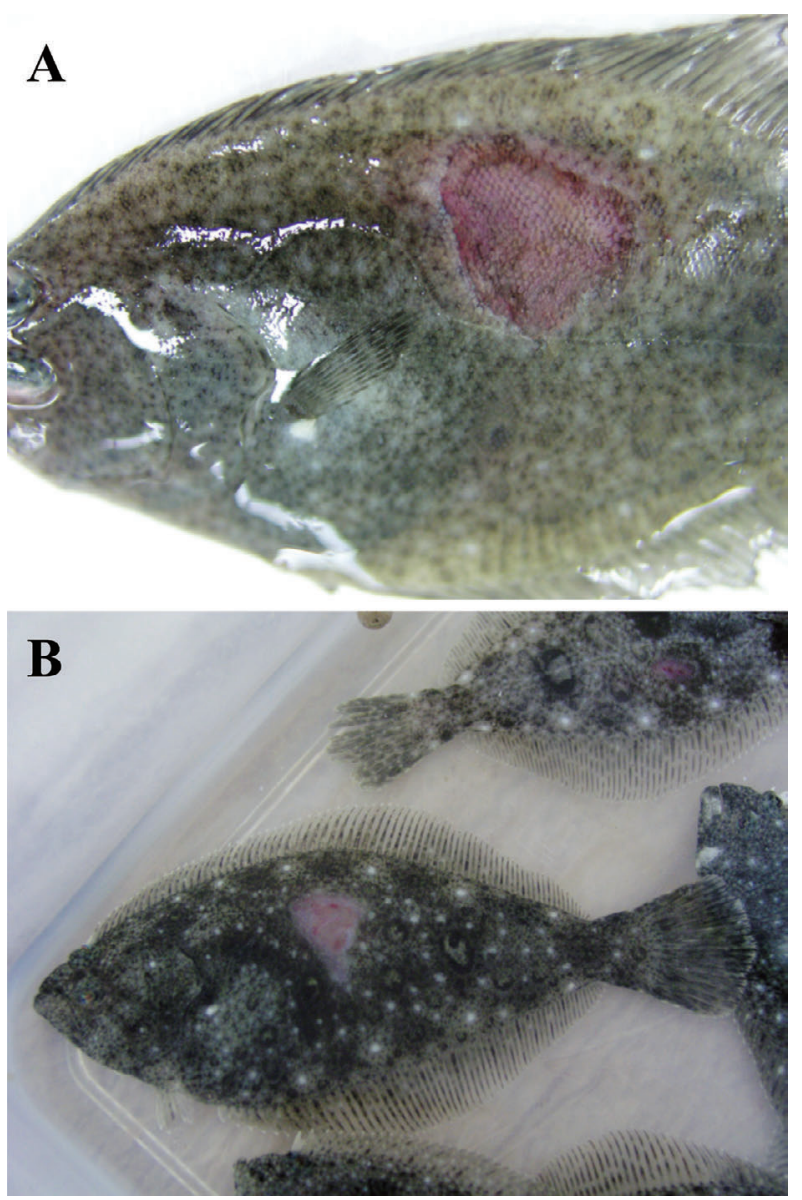

Fig. 2. Photographs of redness of skin and ulceration in the skin around the inoculation site with Poly(I:C). A) redness of skin and $B$ ) ulceration in the skin around the inoculation site.

と考えられる。しかしながら，ヒラメのVHSは，春先の 低水温期に発症する病気であり，冬場の低水温期に Poly (I:C)-免疫法を実施する際には, Poly (I:C) による 毒性に注意を払う必要があるかもしれない。
謝

辞

This study was supported by the Technology Development Program for Fisheries (No. 110091-3) supported by the Ministry for Food, Agriculture, Forestry, and Fisheries, Republic of Korea.

文献

1) Takano, R., T. Nishizawa, M. Arimoto and K. Muroga (2000) : Bull. Eur. Ass. Fish Pathol., 20, 186-192. 2) Takano, R., K. Mori, T. Nishizawa, M. Arimoto and K. Muroga (2001): Fish Pathol., 36, 153-160. 3) Isshiki, T., T. Nishizawa, T. Kobayashi, T. Nagano and T. Miyazaki (2001): Dis. Aquat. Org., 47, 87-99. 4) Kim, W. S., S. R. Kim, D. Kim, J. O. Kim, M. A. Park, S. Kitamura, H. Y. Kim, D. H. Kim, H. J. Han, S. J. Jung and M. J. Oh (2009): Aquaculture, 296, 165-168. 5) Nishizawa, T., H. lida, R. Takano, T. Isshiki, K. Nakajima and K. Muroga (2002): Dis. Aquat. Org., 48, 143-148. 6) Elsayed, E., M. Faisal, M. Thomas, G. Whelan, W. Batts and J. Winton (2006) : J. Fish Dis., 29, 611-619. 7) Kim, W. S, S. J. Jung, J. O. Kim, D. W. Kim, J. H. Kim and M. J. Oh (2011) : J. Fish Pathol., 24, 1-9. 8) Lorenzen, N. and N. J. Olesen (1997): Developments in Biological standardization Fish Vaccinology, vol. 90. Basel: Karger, pp. 201-209. 9) Lorenzen, N., E. Lorenzen, K. Einer-Jensen, J. Heppell, T. Wu and H. Davis (1998): Fish Shellfish Immunol., 8, 261-270. 10) Lorenzen, N., E. Lorenzen, K. Einer-Jensen and S. E. LaPatra (2002) : Fish Shellfish Immunol., 12, 439-453. 11) Heppell, J., N. Lorenzen, N. K. Armstrong, T. Wu, E. Lorenzen, K. Einer-Jensen, J. Schorr and H. L. Davis (1998): Fish Shellfish Immunol., 8, 271-286. 12) Takami, I., S. R. Kwon, T. Nishizawa and M. Yoshimizu (2010): Dis. Aquat. Org., 89, 109-115. 13) Kim, H. J., N. Oseko, T. Nishizawa and M. Yoshimizu (2009): Dis. Aquat. Org., 83, 105-113. 14) Nishizawa, T., I. Takami, Y. Kokawa and M. Yoshimizu (2009): Dis. Aquat. Org., 83, 115-122. 15) Nishizawa, T., I. Takami, M. Yoshimizu and M. J. Oh (2011a): Aquaculture, 331, 100-104. 16) Robinson, R. A., V. T. DeVita, H. B. Levy, S. Baron, S. P. Hubbard and A. S. Levine (1976): J. Natl. Cancer Inst. 57, 599-602. 17) Nishizawa, T., I. Takami, M. Yang and M. J. Oh (2011b) : Vaccine, 29, 8397-8404. 